\title{
Mobbing jako destruktor zachowań organizacyjnych (w świetle badań studentów)
}

\begin{abstract}
Kazimierz Mrozowicz*
Ukazanie stopnia powszechności przemocy $w$ środowisku akademickim jest z jednej strony próba wstępnej charakterystyki zjawiska mobbingu wśród studentów - postrzeganych jako uczestnicy systemu społecznego specyficznej organizacji. Podjęte studium ujmuje to szkodliwe zjawisko jednak dogtębniej, zarówno jako istotny czynnik destabilizujacy, jak i wręcz niszczacy kapitat spoteczny organizacji. Dzieje się to głównie poprzez destrukcje jej kultury. Rzecz jasna autor dokonuje w nim pewnych uproszczeń, do których zdaja się ich upoważniać nie tylko warunki edycyjne, lecz także możliwość syntezy. Tematyka ta bowiem nie stanowi specjalnego novum, chociaż badana zależność wydaje się być intrygująca z punktu widzenia uwarunkowań trwatości organizacji.
\end{abstract}

Słowa kluczowe: kapitał ludzki, rodzaje przemocy, przemoc w środowisku akademickim.

Nadesłany: 22.10.2013 | Zaakceptowany do druku: 28.12.2013

\section{Harassment - destruction of organisational behaviour (in the opinion of students and graduates Polish)}

The following article presents the types of violence and aggression in the environment, and social and professional studies with the participation of Polish students. The aim of this study was to show the degree of prevalence of violence in the academic environment.

Keywords: Human capital, kind of violence, violence in academic environment.

Submitted: 22.10.2013 | Accepted: 28.12.2013

JEL: Y80

Dr Kazimierz Mrozowicz - Katedra Zarządzania Kulturą Fizyczną AWF Katowice.

Adres do korespondencji: AWF Katowice, ul. Mikołowska 72B, 40-065 Katowice; e-mail: k.mrozowicz@ awf.katowice.pl. 


\section{Wstęp}

Celem prezentowanego artykułu uczyniono przedstawienie stopnia znajomości oraz oceny zjawiska mobbingu wśród studentów polskich szkół wyższych. Znacząca część z nich, jako przyszli pracownicy różnorodnych sfer życia społecznego i branż gospodarki, stanowić będzie istotny składnik kapitału społecznego rozmaitych organizacji. Tym bardziej że jako młode pokolenie zasilające kadry organizacyjne staną się w najbliższej przyszłości czynnikiem kształtującym normatywną kulturę organizacji w perspektywie kilkudziesięcioletniego przedziału czasu. Zatem to ich opinie wydają się być kluczowe, ponieważ to od nich zależeć będzie mający obowiązywać $\mathrm{w}$ przyszłości jako społecznie akceptowany wzorzec, zbiór reguł i norm kształtujących system zachowań organizacyjnych pracowników.

Wnioski z zakresu zasygnalizowanej problematyki oparto wynikach badań autorskich ${ }^{1}$.

\section{Mobbing w miejscu pracy}

Agresja jest zjawiskiem powszechnym, dotykającym każdego człowieka. Można zetknąć się z nią już w przedszkolu, na podwórku, w szkole, a później na studiach i w miejscu pracy. Może ona przybierać też różnorakie formy, objawiać się w rozmaity sposób - poprzez przemoc fizyczną, psychiczną, molestowanie seksualne czy też przez tytułowy mobbing.

Zagadnienie mobbingu obecne na szpaltach wydawnictw naukowych i popularnych nie doczekało się dotychczas jednobrzmiącej definicji. Poruszane przez przedstawicieli różnych środowisk naukowych i praktyków, budzi ono stałe kontrowersje interpretacyjne, uniemożliwiając tym samym jednoznaczną i klarowną definicję tego powszechnego skądinąd zjawiska. Przedmiotem prezentowanego artykułu nie jest jednak uzgodnienie spolaryzowanych stanowisk naukowych i praktycznych interpretacji. Autor, o czym wspomniano we wstępie, dążą do wyodrębnienia zespołu czynników, który w drodze kumulacji jako skondensowany agregat współtworzą wieloskładnikową przestrzeń dla zjawiska mobbingu. Nieobecność jasnego wskazania dręczycielskich i agresywnych mechanizmów mobbingu staje się, zdaniem autora, powodem ignorowania przez ludzi nią dotknię- tych nieetycznych zachowań wobec nich samych i innych.

Do ścisłego grona naukowych postaci zajmujących się zagadnieniem mobbingu należą: Peter-Paul Heinemann, Carroll Brodsky, Marie France Hirigoyen, Konrad Lorenz i, cieszacy się opinią niekwestiowanego autorytetu $\mathrm{w}$ dziedzinie mobbingu, niemiecki psychiatra Heinz Leymann (Bechowska-Gebhardt i Stalewski, 2004, s. 15).

Po raz pierwszy terminu „mobbing” użył w 1964 roku etiolog Konrad Lorenzw odniesieniu do sytuacji, w której grupka zwierząt atakowana przez większego osobnika przyjęła defensywna strategie zachowania. Tożsame zjawisko w latach 60. XX wieku odnotował $\mathrm{u}$ małych dzieci Peter-Paul Heinemann, który zaobserwował utrzymujące się, wrogie zachowanie grupy małych dzieci skierowane w stronę innego dziecka. W 1976 roku Carroll Brodsky napisał książkę pt: The Harassed Worker (Napastowany pracownik). Użył w niej terminu harassment, który oznacza napastowanie jako zachowanie pociagające za sobą powtarzające i utrzymujące się próby męczenia i frustrowania współpracownika i wymuszania na nim określonych reakcji (Bechowska-Gebhardt i Stalewski, 2004, s. 25).

Heinz Leymann w latach 80. minionego wieku zastosował ów termin w takim właśnie znaczeniu, odkrywszy odpowiadające mu zachowania występujące pomiędzy pracownikami. Badania mobbingu Leymann zapoczątkował w Szwecji, a następnie kontynuował je w Niemczech. Obserwował on zachowania się tzw. ludzi trudnych w środowisku wykonywania przez nich pracy. W 1984 roku opublikowal raport z przeprowadzonych obserwacji, w którym zawarł konkluzję, iż mobbing jest „psychologicznym terrorem, na który składają się: systematycznie wrogi oraz nieetyczny sposób porozumiewania się członka grupy lub całego zespołu pracowniczego z jednym z jej członków, który został przezeń zepchnięty do pozycji obronnej i pozbawiony pomocy" (Leymann, 1996, s. 45).

Według art. 943 § 2 . kodeksu pracy mobbing oznacza ,działania lub zachowania dotyczące pracownika lub skierowane przeciwko pracownikowi, polegające na uporczywym i długotrwałym nękaniu lub zastraszaniu pracownika, wywołujące u niego zaniżoną ocenę przydatności zawodowej, powodujące lub mające na celu poniżenie lub ośmieszenie pracownika, izolowanie go lub wyeliminowanie z zespołu 
współpracowników” (art. 943 § 1 kp). W obu ujęciach definicyjnych, oddziaływanie mobbingu wywołuje pejoratywne skutki personalne, zespołowe i społeczne, prowadząc do degeneracji kapitału społecznego.

Badania przemocy, agresji i mobbingu w miejscu pracy przeprowadzili w Polsce niemalże równolegle: CBOS w 2002 roku i Katarzyna Delikowska na przełomie 2003/2004 roku. Sondaż CBOS przeprowadzony został na grupie dorosłych Polaków obu płci, zatrudnionych na podstawie umowy o pracę, a także wykonujących pracę jako pracownicy najemni. Pytania badawcze dotyczyły występowania opresj i szykan w miejscu pracy oraz ich rodzajów (Derczyński, 2002). Badania nad mobbingiem Delikowskiej objęły osoby powyżej 18 roku życia: zarówno pracodawców, pracobiorców i bezrobotnych. Wspominana autorka korzystała z klasyfikacji zaproponowanej przez Leymanna (2004), w której wyróżnia się określone grupy zachowań mobbingowych (Delikowska, 2004). Wspomnieć należy, że typologia Leymanna stała się dla autora niniejszego artykułu podstawą opracowania oryginalnego narzędzia badawczego, które zastosowano w ramach zrealizowanego projektu.

Badania dotyczące warunków w miejscu pracy przeprowadzone wśród pracowników 15 krajów Unii Europejskiej wykazały, że każdego roku 6 mln pracowników (4\% wszystkich pracowników) doznaje w miejscu pracy przemocy fizycznej, $12 \mathrm{mln}(8 \%)$ ulega mobbingowi, a $3 \mathrm{mln}(2 \%)$ to ofiary prześladowania seksualnego (Litzke i Schuh, 2006).

Jak wynika z przytoczonych danych, mamy do czynienia ze zjawiskiem uniwersalnym, które cechuje się wyraźnym zasięgiem powszechności nie tylko w młodych, dojrzewających demokracjach, ale też wśród członków społeczeństw obywatelskich.

\section{Przyczyny mobbingu}

Powstanie mobbingu najczęściej posiada wieloczynnikową etiologię. Osobowości stron konfliktu odgrywają w tym zjawisku taką samą rolę, jak kultura organizacyjna i klimat panujący w organizacji, styl zarządzania manifestowany przez przełożonych, preferowane style komunikowania się, system wartości, formalizacja czy warunki środowiskowe.

Przyczyn mobbingu zaleca się poszukiwać w zhierarchizowanych, ,sfeudalizowa- nych" strukturach społecznych, które umożliwiają sprawowanie autokratycznej władzy $\mathrm{z}$ pozycji siły. Typowe negatywne cechy organizacji, w której występuje przemoc psychiczna to miedzy innymi: nieobsadzone stanowiska, mało czasu dla wykonania pilnych zadań, niedorzeczne czy bezsensowne polecenia wydawane podwładnym, obarczanie podwładnego zbyt dużą odpowiedzialnością, przy równoczesnym ograniczaniu prerogatyw decyzyjnych, gratyfikacji i niedocenianie działań podwładnych, zła atmosfera w miejscu pracy oraz brak koleżeńskich zachowań. Wszystko to powoduje, że brak poczucia możliwości uzyskania wsparcia od współpracowników, dają pracownikom poczucie permanentnego zagrożenia, niepewności oraz obawy o utratę pracy (ten ostatni element ogranicza skutecznie ujawnianie opisywanego zjawiska na forum ze strachu przed zwolnieniem) (Kmiecik-Baran i Rybicki, 2004).

\section{Badania poprzedników w wybranych środowiskach zawodowych}

Według wspominanych badań Delikowskiej (2004) mechanizm mobbingu dotyka ogółem 5,6\% pracowników służby zdrowia (personelu pielęgniarskiego), ze strony osób, z którymi współpracują. Mobbing ze strony przełożonych dotkną $4,1 \%$ badanych, ze strony kolegów - 1,1\%, ze strony podwładnych - 1,6\% (procenty te nie sumują się ponieważ ofiara mogła doświadczać mobbingu równocześnie ze strony szefów, kolegów i/lub podwładnych).

Wyniki badań sektora usług wykazały, że narażenie pracowników sfery usług na mobbing osiąga nieco większą skalę - dręczenia doświadczyło ogółem $7,8 \%$ badanych; w sytuacji, gdzie najczęściej sprawcą mobbingu byli szefowie - takich zachowań doświadczyło $5,1 \%$ badanych, w dalszej kolejności: gdy sprawcami mobbingu byli podwładni $-4,7 \% \mathrm{i}$ - koledzy ofiar $-2,9 \%$.

Badania Pomorskiego Instytutu Demokratycznego z 2002 roku prowadzono z udziałem 492 przedstawicieli oświaty (nauczycieli, pedagogów i wychowawców). Wykazały one, że $61,5 \%$ badanych było poddawanych mobbingowi dłużej niż pół roku. Przy czym warto podkreślić, że w badaniach tych jako „mobbing” zaklasyfikowano również „wyzysk ekonomiczny”, ,wymuszanie decyzji” i ,stwarza- 
nie fikcyjnych problemów" (Kmiecik-Baran i Rybicki, 2004).

Jako konsekwencje doświadczania mobbingu badani wymienili: depresję, problemy ze snem, problemy ze zdrowiem fizycznym, nadużywanie alkoholu, zmianę pracy, korzystanie ze zwolnień lekarskich z pracy, kłopoty finansowe i konflikty w rodzinie (Kmiecik-Baran i Rybicki, 2004).

Badania Demokratycznej Unii Kobiet we Wrocławiu oraz Dolnoślaskiego Forum Stowarzyszeń i Środowisk Kobiecych z 2002 i 2003 roku, które objęły grupe 243 losowo wybranych osób wykazały, że poszczególnych rodzajów zachowań wchodzących w zakres mobbingu (tzn. wymienionych przez Leymanna) doświadczyła grupa od 6,8 do 47,2\% osób. Przy czym najczéściej działania „mobberów” koncentrowały sie na naruszaniu dobrego wizerunku ofiary w miejscu pracy. Koszty ponoszone przez nie to $\mathrm{z}$ reguly: koszty finansowe, incydentalne zwolnienia lekarskie $\mathrm{z}$ pracy, ciągłe zwolnienia, mniejsza efektywność pracy, brak motywacji do pracy i popełnianie błędów w pracy (Delikowska, 2004).

\section{Metodyka badań własnych}

Na przełomie kwietnia i maja 2012 roku zespół badawczy pod kierownictwem autora, w którego skład weszli członkowie koła naukowego i inni studenci Państwowej Wyższej Szkoły Techniczno-Ekonomicznej kierunku europeistyka w Jarosławiu, przygotował własny projekt badawczy pt.: Zjawisko mobbingu w opinii polskich studentów.

Przeprowadzono badania ankietowe na losowo pobranej 240 osobowej próbie badawczej (120 kobiet i 120 mężczyzn) w przedziale wiekowym 19-27 lat, w trzech środowiskach akademickich Polski: jarosławskim (Państwowa Wyższa Szkoła Techniczno-Ekonomiczna), rzeszowskim (Uniwersytet Rzeszowski) oraz katowickim (AWF) wśród studentów studiów licencjackich stacjonarnych i niestacjonarnych kierunku turystyka i rekreacja.

Pierwszoplanowym celem badań było ukazanie skali zjawiska mobbingu w środowisku akademickim studentów polskich uczelni. W ramach przeprowadzonych badań odpowiadano na pytania:

- czy kiedykolwiek byłeś świadkiem wymienionych zachowań oraz czy kiedykolwiek byłeś ofiarą wymienionych zachowań typu: złośliwe uwagi, przedrzeźnianie oraz ośmieszanie, ograniczanie możliwości wypowiadania się, obgadywanie i rozsiewanie plotek, traktowanie jak powietrze, natarczywe telefony, publiczna krytyka, używanie wyzwisk i krzyków, okazywanie niechęci, wyśmiewanie się z poglądów politycznych czy religijnych, agresywne zachowanie, przemoc psychiczna, napastowanie na tle seksualnym, niemoralne propozycje?

- kto stosowal wymienione działania: zarówno z perspektywy świadka, jak i ofiary?

- jak długi był czas trwania działań?

- jakie były działania podjęte przez ofiare w zaistniałej sytuacji?

Do analizy postawionych pytań badawczych opracowano i zastosowano kwestionariusz ankiety pt. Kwestionariusz analizy postaw. Oryginalna wersje kwestionariusza załączono do prezentowanego artykułu (zob. Aneks).

Należy wyraźnie podkreślić, iż pytania ankietowe sformułowane zostały w taki sposób, aby bezpośrednio nie używano w nich słowa mobbing i jego semantycznych pochodnych. Nie stosowano terminu - desygnatu, lecz jego treść i znaczenie. O znajomość znaczenia słowa „mobbing” zapytano ankietowanych dopiero w końcowej części ankiety, by wyeliminować ewentualność niewłaściwego rozumienia wzmiankowanego terminu.

\section{Mobbing w świetle opinii studentów wybranych uczelni polskich}

Na podstawie analizy wyników badań odnotowano, że nieco więcej kobiet niż mężczyzn deklaruje, iż było świadkami przemocy (64\% kobiet, $58 \%$ mężczyzn), natomiast $12 \%$ kobiet i $11,5 \%$ mężczyzn nie ma zdania na ten temat. Mężczyźni rzadziej dostrzegaja przemoc w swoim środowisku (30\%). W konkluzji można stwierdzić, że kobiety jako bardziej empatyczne i emocjonalne są wrażliwsze na sygnały nieodpowiedniego czy wrogiego zachowania w stosunku do innych osób. Méżczyźni zaś wydają się być bardziej obojętni, ignorujący zachowania tego rodzaju, traktujący je jako coś normalnego, niewykraczającego poza przyjęte i obowiązujące normy.

Tabela 1 zawiera zestaw 14 rodzajów zachowań mobbingowych Leymanna i procent odpowiedzi potwierdzających częstotli- 
Tabela 1. Dominujące obserwacje zachowań mobbingowych w opinii badanych w porządku malejącym

\begin{tabular}{|l|c|l|c|}
\hline \multicolumn{4}{|c|}{$\begin{array}{c}\text { Czy kiedykolwiek byłeś/aś świadkiem takich zachowań, jak: } \\
\text { (rekuza diagnostyczna - tak) }\end{array}$} \\
\hline \multicolumn{1}{|c|}{$\begin{array}{c}\text { rodzaj zachowania w opinii } \\
\text { badanych kobiet }\end{array}$} & $\begin{array}{c}\text { wynik } \\
\text { (w \%) }\end{array}$ & $\begin{array}{c}\text { rodzaj zachowania w opinii } \\
\text { badanych mężczyzn }\end{array}$ & $\begin{array}{c}\text { wynik } \\
\text { (w \%) }\end{array}$ \\
\hline złośliwe uwagi & 96,6 & złośliwe uwagi & 81,7 \\
\hline obgadywanie i rozsiewanie plotek & 90,8 & obgadywanie i rozsiewanie plotek & 78,3 \\
\hline przedrzeźnianie, ośmieszanie & 87,5 & używanie wyzwisk i krzyków & 77,5 \\
\hline używanie wyzwisk i krzyków & 80,0 & przedrzeźnianie, ośmieszanie & 76,7 \\
\hline okazywanie niechęci & 80,0 & agresywne zachowanie & 73,3 \\
\hline traktowanie jak powietrze & 75,8 & okazywanie niechęci & 62,5 \\
\hline publiczna krytyka & 70,8 & publiczna krytyka & 61,7 \\
\hline $\begin{array}{l}\text { ograniczanie możliwości wypowia- } \\
\text { dania się }\end{array}$ & 70,0 & $\begin{array}{l}\text { ograniczanie możliwości wypowia- } \\
\text { dania się }\end{array}$ & 60,0 \\
\hline agresywne zachowanie & 67,5 & traktowanie jak powietrze & 60,0 \\
\hline $\begin{array}{l}\text { wyśmiewanie się z poglądów poli- } \\
\text { tycznych czy religijnych }\end{array}$ & 54,2 & $\begin{array}{l}\text { wyśmiewanie się z poglądów poli- } \\
\text { tycznych czy religijnych }\end{array}$ & 45,0 \\
\hline natarczywe telefony & 41,7 & przemoc psychiczna & 43,3 \\
\hline przemoc psychiczna & 38,4 & niemoralne propozycje & 41,7 \\
\hline niemoralne propozycje & 32,5 & natarczywe telefony & 36,7 \\
\hline napastowanie na tle seksualnym & 12,5 & napastowanie na tle seksualnym & 13,3 \\
\hline
\end{tabular}

Źródło: badania własne autora.

wość obserwacji przez badanych ich występowania w środowisku akademickim.

Do najczęściej wskazywanych przez kobiety zachowań mobbingowych zaliczają się: złośliwe uwagi - 96,6\%, obgadywanie i rozsiewanie plotek $-90,8 \%$, przedrzeźnianie oraz ośmieszanie $-87,5 \%$. Co ciekawe płeć nie stała się w tym zakresie kryterium różnicującym.

Wśród mężczyzn najczęściej wskazywane były: złośliwe uwagi - 81,7\%, obgadywanie i rozsiewanie plotek $-78,3 \%$ oraz używanie wyzwisk i krzyków - 77,5\%.

$\mathrm{Na}$ pytanie, kto był mobberem, najwięcej procent zarówno kobiet, jak i mężczyzn wskazało na studentów z innej grupy bądź roku (33\% kobiet i 34\% mężczyzn, zob. wykres 1). Co ciekawe, ale też oburzające, blisko $18 \%$ kobiet i $15 \%$ mężczyzn wskazało nauczycieli akademickich jako stosujaccych niestosowne zachowania wobec studentów. W odniesieniu do studentów

Wykres 1. Osoby wywierające negatywne oddziaływania (,,mobberzy”) w opinii świadków

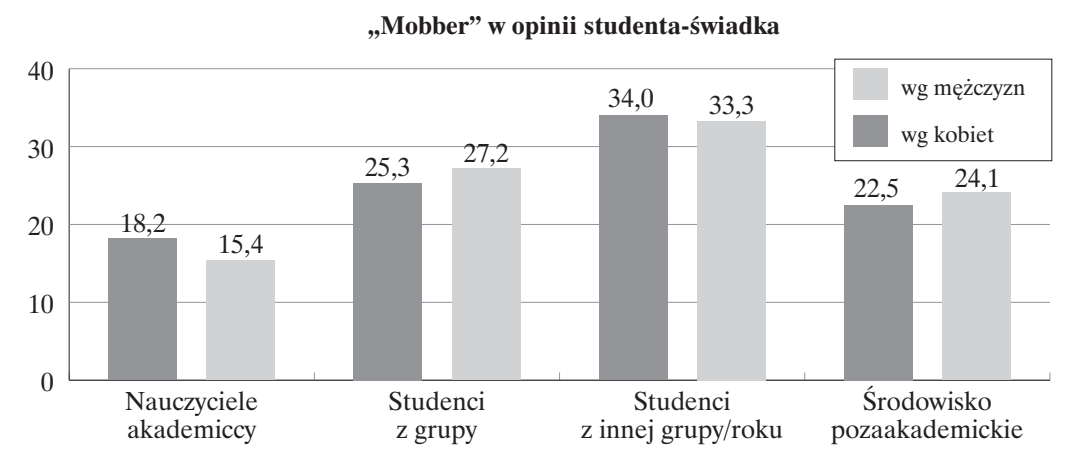

Źródło: badania własne autora. 
Tabela 2. Dominujące rodzaje zachowań mobbingowych, których ofiarą padli studenci uczelni polskich w porządku malejącym

\begin{tabular}{|l|c|l|c|}
\hline \multicolumn{4}{|c|}{$\begin{array}{c}\text { Czy byłeś/aś ofiarą takich zachowań, jak: } \\
\text { (rekuza diagnostyczna - tak) }\end{array}$} \\
\hline $\begin{array}{c}\text { rodzaj zachowania w opinii bada- } \\
\text { nych kobiet }\end{array}$ & $\begin{array}{c}\text { wynik } \\
\text { (w \%) }\end{array}$ & $\begin{array}{c}\text { rodzaj zachowania w opinii bada- } \\
\text { nych mężczyzn }\end{array}$ & $\begin{array}{c}\text { wynik } \\
\text { (w \%) }\end{array}$ \\
\hline złośliwe uwagi & 60,8 & złośliwe uwagi & 55,0 \\
\hline obgadywanie i rozsiewanie plotek & 58,3 & obgadywanie i rozsiewanie plotek & 50,0 \\
\hline przedrzeźnianie, ośmieszanie & 43,3 & używanie wyzwisk i krzyków & 47,5 \\
\hline używanie wyzwisk i krzyków & 37,5 & przedrzeźnianie, ośmieszanie & 45,0 \\
\hline okazywanie niechęci & 35,0 & agresywne zachowanie & 39,2 \\
\hline traktowanie jak powietrze & 32,5 & okazywanie niechęci & 37,5 \\
\hline publiczna krytyka & 30,0 & publiczna krytyka & 35,0 \\
\hline $\begin{array}{l}\text { ograniczanie możliwości wypowia- } \\
\text { dania się }\end{array}$ & 27,5 & $\begin{array}{l}\text { ograniczanie możliwości wypowia- } \\
\text { dania się }\end{array}$ & 31,7 \\
\hline agresywne zachowanie & 22,5 & traktowanie jak powietrze & 30,8 \\
\hline $\begin{array}{l}\text { wyśmiewanie się z poglądów poli- } \\
\text { tycznych czy religijnych }\end{array}$ & 20,0 & $\begin{array}{l}\text { wyśmiewanie się z poglądów poli- } \\
\text { tycznych czy religijnych }\end{array}$ & 27,5 \\
\hline natarczywe telefony & 15,8 & przemoc psychiczna & 23,3 \\
\hline przemoc psychiczna & 12,5 & niemoralne propozycje & 22,5 \\
\hline niemoralne propozycje & 11,7 & natarczywe telefony & 17,5 \\
\hline napastowanie na tle seksualnym & 3,3 & napastowanie na tle seksualnym & 17,5 \\
\hline
\end{tabular}

Źródło: badania własne autora.

z tej samej grupy i środowiska pozaakademickiego wynik oscyluje między 22 a 27\%, czyli jest stosunkowo niższy.

Połowa ankietowanych kobiet (50\%) i mężczyzn $(48,6 \%)$ deklaruje, iż nie stała się ofiarą negatywnych działań, przy tym $34 \%$ mężczyzn i $29 \%$ kobiet przyznaje, że stosowano wobec nich działania uznawane za mobbingowe.

Na pytanie o dominujące rodzaje mobbingu, których ankietowani sami stali się ofiarami (por. tab. 2), kobiety wskazywały: obgadywanie i rozsiewanie plotek - 60,8\%, złośliwe uwagi - 58,3\%, przedrzeźnianie i ośmieszanie - 43,3\%, podczas gdy mężczyźni: złośliwe uwagi - 55\%, używanie wyzwisk i krzyków - 50\%, przedrzeźnianie i ośmieszanie - 47,5\%.

Rekapitulując wyniki badań, daje się zauważyć, że więcej studiujących mężczyzn niż kobiet przyznaje się do bycia ofiarą mobbingu. Różnice te zauważalne są w szczególności w przypadku zachowań typu:

- używanie wyzwisk i krzyków (20\% różnica: $30 \%$ kobiet i $50 \%$ mężczyzn),

- agresywne zachowania (17\% różnica: $20 \%$ kobiety i $37 \%$ mężczyzn),
- napastowanie na tle seksualnym $(14 \%$ różnica: 3,3\% kobiet i 17,5\% mężczyzn), - niemoralne propozycje (7\% różnica: $15,8 \%$ kobiet i $22,5 \%$ mężczyzn).

Zdaniem kobiet-ofiar, stosującymi wobec nich niepożądane działania najcześsciej byli studenci z innej grupy/roku - 32,6\% (wykres 2). Mężczyźni-ofiary wskazywali natomiast na środowisko pozaakademickie - 35,7\%. Nauczyciele akademiccy uplasowali się na czwartej ostatniej pozycji, z wynikiem $10 \%$ wskazań przez kobiety i $7 \%$ przez mężczyzn.

Jeżeli chodzi o czas trwania agresywnych zachowań, ankietowani, spośród 4 możliwych wariantów, najczęściej wskazywali na okres poniżej 1 miesiaca (44\% kobiet i $49 \%$ mężczyzn). Okres od 1 do 6 miesięcy jako czas trwania niepożądanych działań wskazało $25 \%$ kobiet i $21 \%$ mężczyzn. Po $15 \%$ obie płcie wskazały na okres między 6 a 12 miesięcy. Aż $15 \%$ mężczyzn i $16 \%$ kobiet opowiedziało się za tym, że przez okres 1 roku były ofiarami agresywnych zachowań.

Bardzo ciekawych interpretacyjnie danych dostarcza wykres 3 , przedstawiający rodzaje reakcji osoby mobbowanej (wykres 3). 
Wykres 2. Osoby wywierające negatywne oddziaływania (,,mobberzy”) w opinii ofiar

Kto byl „mobberem” wedlug ofiary?

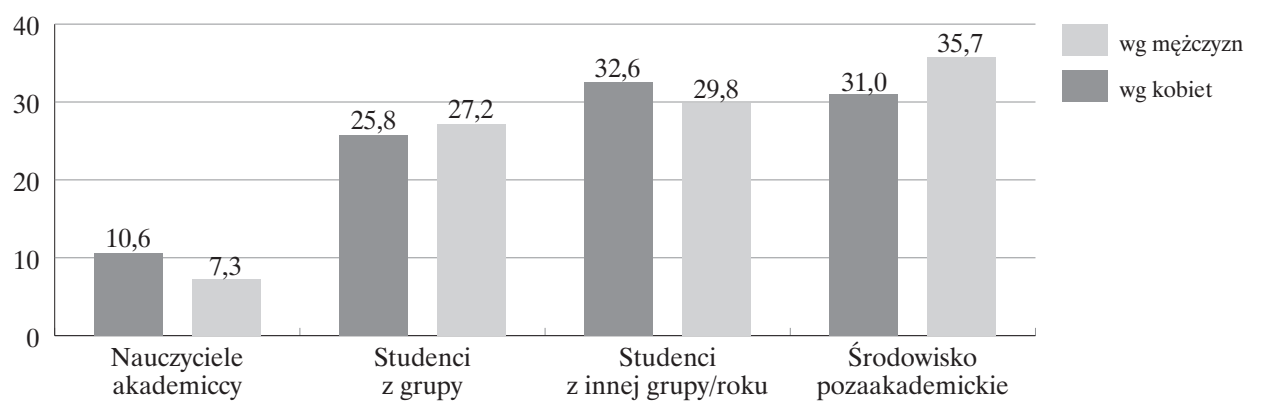

Źródło: badania własne autora.

Wykres 3. Reakcje osoby mobbowanej

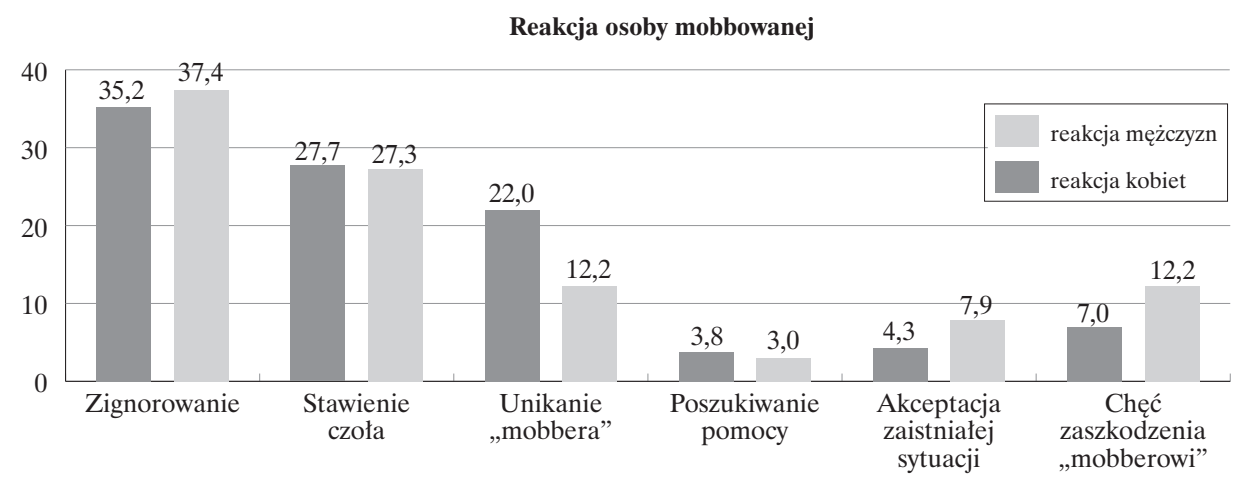

Źródło: badania własne autora.

Wykres 4. Znajomość terminu „mobbing” wśród badanych

Czy znasz pojęcie „mobbingu”?

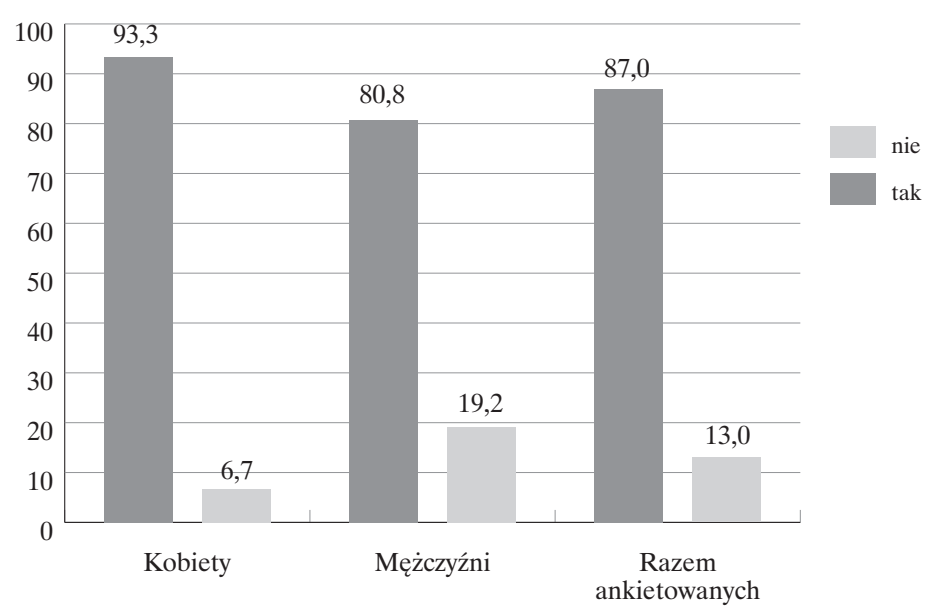

Źródło: badania własne autora. 
Niepokojącą reakcją na mobbing jest to, iż ofiary najczęściej ignorują zaistniałą sytuację, nie podejmując żadnych czynności retorsyjnych i zapobiegawczych. Niestety tylko $4 \%$ kobiet i 3\% mężczyzn poszukuje jakiejkolwiek pomocy, podejmując działania zapobiegawcze. Spowodowane jest to brakiem wiedzy osoby poszkodowanej, do kogo lub gdzie może się ona zwrócić o pomoc. Około $27 \%$ ankietowanych obu płci starała się stawić czoła opresjom. Znamienny jest fakt tego, iż 7\% kobiet i $12 \%$ mężczyzn zadeklarowało chęć odwetu i zaszkodzenia mobberowi, co przewyższa procent osób poszukujących pomocy. Kobiety unikają mobberów i nie chcą im szkodzić, być może $\mathrm{z}$ powodu lęku przed pogorszeniem swojej sytuacji, natomiast mężczyźni wręcz przeciwnie.

Na zakończenie ankiety zadano pytanie: czy znasz pojęcie mobbingu?, na które $87 \%$ ankietowanych odpowiedziało twierdząco (93\% kobiet i $80 \%$ mężczyzn - wykres 4 ).

$19 \%$ mężczyzn i blisko $7 \%$ kobiet przyznaje, iż pojecie to jest im obce. Co należy rozumieć w ten sposób, iż badani znają treść pojęcia, lecz nie znają jego desygnatu. Stąd być może stosunkowo niski poziom działań wspierających i poszukiwania pomocy, ponieważ badani nie potrafią się upomnieć o odpowiednią jej formę.

\section{Destrukcyjne skutki mobbingu dla kapitału ludzkiego}

Destrukcyjny wpływ mobbingu wyraża się przede wszystkim w eskalacji wymiernych kosztów i pojawianiu się nadmiernych strat, do których zalicza się zwykle: obniżenie wydajności, straty wynikające ze wzmożonej absencji w pracy i wypadków spowodowanych stresem, zdenerwowaniem, koszty procesów sądowych oraz odszkodowań dla pracowników bezpodstawnie zwolnionych, pogorszenie jakości pracy wynikajace z obniżonego morale kadr i błęów w kierowaniu ludźmi, problem fluktuacji personelu, koszty procedur rekrutacyjnych, szkolenia nowych pracowników, wdrożenia do pracy, niedotrzymywanie terminów, niższą jakość świadczonych usług, mniejszą efektywność, koszty administracyjne związane ze zwalnianiem pracowników oraz zatrudnianiem nowych osób.

Do strat niewymiernych, można zaliczyć spadek zaufania do kierownictwa i pogor- szenie się klimatu organizacyjnego, wzrost postaw egotycznych wynikających z izolacji społecznej oraz nieufności pracowników wobec kierownictwa i samych siebie, naruszenie lub zmiana publicznego wizerunku organizacji, zaburzenia relacji interpersonalnych etc.

\section{Zakończenie}

Działania mobbingowe oraz klimat zastraszania powodują bierność pracowników, rutynę, schematyzm myślenia i działania, brak kreatywności i niekonwencjonalnego, nowatorskiego podejścia do różnych problemów organizacji, jak również brak alternatywnych i innowacyjnych pomysłów, planów, projektów w celach poszerzenia oferty i zwiększenia konkurencyjności na rynku, co przekłada się na efekty uzyskiwane przez zasoby ludzkie organizacji.

Na skutek tych działań obniża się równocześnie wydajność i efektywność samej kadry kierowniczej, zajętej stosowaniem mobbingu, która zamiast koncentrować się na bieżących i strategicznych problemach organizacyjnych, niszczy posiadany potencjał pracowników.

\section{Przypis}

1 Badania własne przeprowadził zespół studentów europeistyki Instytutu Stosunków Międzynarodowych PWSTE w Jarosławiu pod kierunkiem dr Kazimierza Mrozowicza w składzie: Joanna Kula, Karolina Kościuk oraz Kamil Kusiński.

\section{Bibliografia}

Bechowska-Gebhardt, A., Stalewski, T. (2004). Mobbing, patologia zarzadzania personelem. Warszawa: Wydawnictwo Difin.

Delikowska, K. (2004). Raport z badań na temat dziatań mobbingowych $w$ miejscu pracy. Spotecznik, 7. http://badanie.cbos.pl/details.asp?q=a1\&id=2731. http://www.leymann.se.

Kmiecik-Baran, K. i Rybicki, J. (2004). Mobbing - zagrożenie wspótczesnego miejsca pracy. Gdańsk: Wydawnictwo Pomorski Instytut Demokratyczny.

Leyman, H. (1996). The content and development of mobbing at work. European Journal of Work and Organizational Psychology.

Litzke, S.M. i Schuh, H. (2006). Stres, mobbing

$i$ wypalenie zawodowe. Gdańsk: GWP. 


\section{Aneks}

\section{KWESTIONARIUSZ ANALIZY POSTAW}

Celem niniejszej ankiety postanowiliśmy uczynić przekonania dorosłych Polaków na temat nurtujących ich problemów społecznych oraz zawodowych. Wyniki niniejszej ankiety posłużą celom naukowym, a także prawdopodobnym rozwiązaniom praktycznym w wybranych środowiskach społecznych i zawodowych. Ankieta jest całkowicie anonimowa. Jako autorzy badań uprzejmie prosimy o szczere i zgodne z prawdą odpowiedzi. Wybór w pełni odpowiadający Twoim poglądom prosimy oznaczyć krzyżykiem (X) w odpowiednim polu.

1. Płeć:

kobieta

mężczyzna

2. Twoje środowisko społeczne:

środowisko akademickie

środowisko pozaakademickie

3. Twój wiek:

4. W jakim mieście znajduje się twoja uczelnia?

5. Rok studiów: nie dotyczy:

6. Zawód: bezrobotny:

7. Czy kiedykolwiek byłeś/aś świadkiem takich zachowań, jak:

\begin{tabular}{|l|l|l|l|}
\hline & Tak & Nie wiem & Nie \\
\hline Złośliwe uwagi & & & \\
\hline Przedrzeźnianie, ośmieszanie & & & \\
\hline Ograniczanie możliwości wypowiadania się & & & \\
\hline Obgadywanie, rozsiewanie plotek & & & \\
\hline Traktowanie jak powietrze & & & \\
\hline Natarczywe telefony & & & \\
\hline Publiczna krytyka & & & \\
\hline Używanie wyzwisk i krzyków & & & \\
\hline Okazywanie niechęci & & & \\
\hline Wyśmiewanie się z poglądów politycznych czy religijnych & & & \\
\hline Agresywne zachowanie & & & \\
\hline Przemoc psychiczna & & & \\
\hline Napastowanie na tle seksualnym & & & \\
\hline Niemoralne propozycje & & & \\
\hline Inne & & & \\
\hline
\end{tabular}


9. Kto stosował wymienione powyżej działania?

nauczyciele akademiccy

studenci z twojej grupy

studenci z innej grupy lub innego roku

nie dotyczy

10. Płeć osoby stosującej wymienione powyżej działania:

kobieta

mężczyzna

nie dotyczy

11. Czy byłeś/aś lub jesteś ofiarą takich zachowań, jak?

\begin{tabular}{|l|l|l|l|}
\hline & \multicolumn{1}{|c|}{ Tak } & Raczej nie & Nie \\
\hline Złośliwe uwagi & & & \\
\hline Przedrzeźnianie, ośmieszanie & & & \\
\hline Ograniczanie możliwości wypowiadania się & & & \\
\hline Obgadywanie, rozsiewanie plotek & & & \\
\hline Traktowanie jak powietrze & & & \\
\hline Natarczywe telefony & & & \\
\hline Publiczna krytyka & & & \\
\hline Używanie wyzwisk i krzyków & & & \\
\hline Okazywanie niechęci & & & \\
\hline Wyśmiewanie się z poglądów politycznych czy religijnych & & & \\
\hline Agresywne zachowanie & & & \\
\hline Przemoc psychiczna & & & \\
\hline Napastowanie na tle seksualnym & & & \\
\hline Niemoralne propozycje & & & \\
\hline Inne & & & \\
\hline
\end{tabular}

12. Jeżeli zaznaczyłeś/aś odpowiedź „Inne”, proszę wymienić jakie?

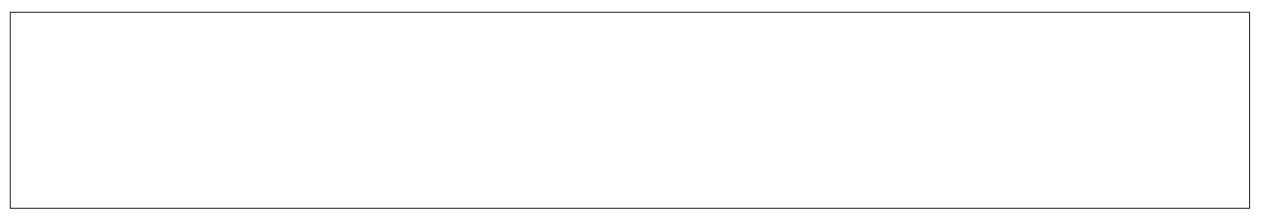

Wydział Zarządzania UW ～DOI 10.7172/1733-9758.2013.16.8 
13. Kto stosował wymienione powyżej działania?

nauczyciele akademiccy

studenci z twojej grupy

studenci z innej grupy lub innego roku

nie dotyczy

14. Zaznacz płeć osoby dopuszczającej się wymienionych działań i częstotliwość ich występowania:

\begin{tabular}{|l|l|l|l|l|}
\hline & Bardzo często & Często & Rzadko & Bardzo rzadko \\
\hline Kobieta & & & & \\
\hline Mężczyzna & & & & \\
\hline
\end{tabular}

15. Jak długo trwały wyżej wymienione działania?
poniżej 1 miesiąca
1-6 miesięcy
6-12 miesięcy
powyżej 1 roku

16. Jak postąpiłeś/aś w zaistniałej sytuacji?

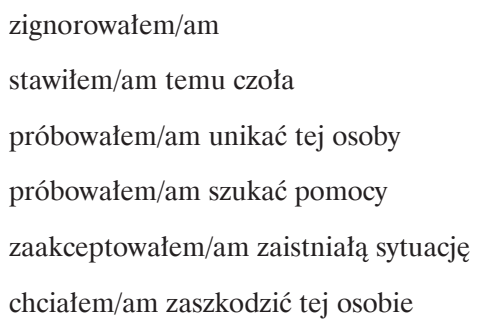

17. Czy znasz pojęcie „mobbingu” ?

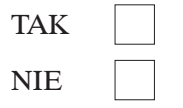

Dziękujemy za współpracę! 